\title{
Determinants of currency crises in the Republic of Serbia $^{* 1}$
}

\author{
Ivana Marjanović ${ }^{2}$, Milan Marković3
}

\begin{abstract}
The aim of this study is to overcome the lack of empirical research dealing with the main factors of currency crises in the Republic of Serbia, analyzing periods of currency crises and creating an early warning system to anticipate the upcoming currency crises. Using econometric analysis, this paper examines the determinants of currency crises episodes during the period from January 2007 to May 2018, and based on this, it makes proposals for economic policy makers. It has been shown that dominant factors are those that bind mostly with the effect of factors from the external environment, which is important in assessing and forecasting potential crises in the Republic of Serbia. More specifically, the obtained results indicate that the overvaluation of the national currency, current account balance as a percentage of GDP, imports and stock exchange index are statistically significant variables.
\end{abstract}

Key words: currency crisis, early warning system, EMP index, probit model

JEL classification: $C 25, F 30, F 31, F 47$

\footnotetext{
* Received: 20-02-2019; accepted: 28-05-2019

1 The work was done within the project of the Ministry of Education, Science and Technological Development of the Republic of Serbia, number 179066, titled "Improving the competitiveness of the public and private sector by networking competencies in the process of the European integration of Serbia".

${ }^{2}$ Research Trainee, University of Niš, Innovation Center, Univerzitetski trg 2, 18000 Niš, Serbia. Scientific affiliation: operational research. Phone: +381 18528 655. E-mail: ivana. veselinovic@eknfak.ni.ac.rs.Website: http://www.icun.ni.ac.rs/index.php/sr/ivana-marjanovic (corresponding author).

${ }^{3}$ Research Assistant, University of Niš, Innovation Center, Univerzitetski trg 2, 18000 Niš, Serbia. Scientific affiliation: economic policy. Phone: +381642885134.E-mail: markovicmilan89@ gmail.com. Website: http://www.icun.ni.ac.rs/index.php/sr/milan-markovic.
} 


\section{Introduction}

Currency crises are mainly the result of a macroeconomic imbalance, which is most often reflected in the fiscal deficit and the deficit of foreign trade. Based on the theoretical nature and causes of the crisis, three theoretical models of currency crises can be identified (Babić and Žigman, 2001). The first-generation models are found in the work of Krugman (1979), and their essence is that the breakdown of a fixed exchange rate regime is triggered by an unsustainable fiscal policy (Burnside, et al., 2008). These models focus on poor economic policy which causes tenacious and rising macroeconomic difficulties. Consequently, due to growing and unsustainable macroeconomic problems, investors attack domestic currency, which leads to its depreciation (Ari, 2012). The unsustainable movement of certain economic indicators, such as public debt, budget deficit or excessive expansionary economic policy, are the main factors present in the models of the first generation of currency crises. The growth of the budget deficit drains the central bank's foreign exchange reserves, which jeopardizes the sustainability of the applied exchange rate regime. The second-generation models of currency crises are first described in Obstfeld (1986), and the main focus is on the market itself, and not only on the economic policies of the government. According to second-generation models, the currency is mainly affected by self-fulfilling expectations and market panics, and also by "triggers" that influence expectations to move in the same direction (Babić and Žigman, 2001). If there are positive expectations of the majority, there is no attack. Otherwise, negative expectations occur when economic policy is not kept adequately and deviates from the optimal one, which affects the growth of the balance of payments deficit and the possibility that the domestic currency will be overestimated. Then, according to the "effect of the herd", investors react in such a way that the exchange rate is defended depending on the amount of foreign exchange reserves available to the monetary authority. Therefore, a crisis may be triggered without the previous substantial worsening of macroeconomic fundamentals. In order to explain the emergence of the Asian financial crisis, the models of the third generation of currency crises were developed. The thirdgeneration models mostly focus on the distortions in the banking and financial system that cause different types of problems mainly reflected in liquidity problems, moral hazard lending problems, bank runs and balance sheet problems caused by foreign debts (Nakatani, 2017). Therefore, the occurrence of the currency crisis is caused by accumulated difficulties in the financial and banking sector and by foreign borrowing. Theoretically, government guarantees focused on attracting foreign investment generate a bubble in the asset market that ultimately bursts and generates the crisis (Cuaresma and Slacik, 2009).

The issue of adequate analysis and prevention of the currency crises outbreak has become exceptionally important for economic policy makers in many countries, especially after the recent global financial crisis, which has highlighted the 
importance of creating and evaluating the performance of early warning systems which can provide a quantitative assessment of the likelihood of a currency crisis in the short term (Comelli, 2014). The financial crisis has particularly pointed to the fact that it can be easily transmitted to the real sector and in most cases causes a currency crisis. The subject of the research is the evaluation of the currency crises episodes in the Republic of Serbia using the probit model, as well as the determination of factors on the basis of which currency crisis can be predicted in the future period.

The objective is to create an early warning system model which will be able to detect the crisis incidence and more importantly, the determinants of the crisis. Analyzed determinants are divided into three groups: macroeconomic variables representing the adequacy of economic policy management; indicators vulnerable to external environmental shocks; and factors of financial liberalization. On the basis of ex post analysis, the aim is to determine which indicators have a statistically significant impact on the emergence of the currency crisis in Serbia, and then which group of variables has a dominant role. The contribution of the study is reflected in the fact that the factors of the currency crisis and the possibility of their emergence through probit technique have not been evaluated on the example of the Republic of Serbia. The results of the study show that adverse movements of variables vulnerable to external environmental shocks, such as current account deficits in relation to the GDP, imports and real exchange rate misalignment have the greatest impact on the likelihood of forthcoming currency crises. These are important results that can be used by policymakers in the conduct of monetary, fiscal and foreign exchange policies.

Significant consequences that the currency crisis can have on the public and private sector have caused the emergence of a large number of research aimed at determining the causes and nature of currency crises with the intention of providing a tool for forecasting forthcoming crises. The main hypothesis of the survey is that episodes of currency crises in the Republic of Serbia are due to distortions of variables reflecting external vulnerability.

The analysis consists of three phases: in the first phase, the periods of crises are identified using the Exchange Market Pressure (EMP) index; in the second phase, the selection of the variables causing the crisis is conducted based on the relevant literature; in the third phase, the specified econometric model is assessed using probit analysis. The rest of the paper is structured as follows. Section 2 gives the review of the relevant literature, while section 3 describes the methodology used in this paper. Section 4 presents empirical data and analysis. Section 5 is dedicated to the discussion of results. Concluding remarks are presented in section 6 . 


\section{Literature review}

Numerous empirical studies dealt with the topic of currency crises, both single and multi-country studies. In order to timely determine the likelihood of a crisis and to provide an adequate response, it is necessary to develop an appropriate methodology on the basis of which crisis forecasting will be carried out. Several non-parametric and parametric approaches can be applied. The most commonly used non-parametric approach is signal approach. On the other hand, there are several parametric approaches, such as discrete choice models or linear regression models. Lately, several innovative approaches gained a lot of attention among researchers - binary recursive trees, artificial neural networks and Markov's switching models.

Signal approach was proposed by Kaminsky, Lizondo and Reinhart (KLR) (1998). They suggested an early warning system which is based on monitoring the movement of certain indicators that record unusual comportment in the pre-crisis period. When some of the monitored indicators go beyond a certain threshold, a "signal" is issued. This signal represents a warning that crisis may occur within the next 24 months. The results of their research showed that indicators with the most success in issuing trustworthy crisis signals are exports, real exchange rate misalignments, GDP growth, equity prices and the ration of money stock to gross international reserves. Balaga and Padhi (2017) used the KLR methodology to examine India's vulnerability to the currency crisis between January 1986 and December 2015. Obtained results indicated that the KLR methodology successfully predicted currency crises in India in 1991, 2008-2009 and 2012. The main causes of the stated currency crises were different: the crisis in 1991 happened due to fiscal mismanagement; the crisis in 2008-2009 was accredited to global financial crisis and the crisis in 2012 was caused by national macroeconomic disparities. Kaminsky and Reinhart (1999) used the KLR signal approach to analyze the relations between the banking and currency crisis. Their results specify that, in most cases, problems in the banking sector precedethe currency crisis while the currency crisis excavates the banking crisis. They have provided a general conclusion that crises episodes happen when the economy enters the recession after a longer period of high economic activity powered by capital inflows, credit and followed by an overvalued currency.

Several authors have tested the prognostic strength of the KLR methodology and compared different methods for forecasting currency crises. In some cases, the quality of anticipation was rather poor. Berg and Pattillo (1999) wanted to test the predictive power of the KLR approach compared to a regression-based approach. Their results implied that a regression-based approach produced more accurate predictions than the KLR approach. However, in both models the same variables were found to be significant predictors of the crisis: overvalued real exchange rate, 
low foreign exchange reserves growth, low export growth, high growth of broad money to foreign reserves ratio and high current account deficit. Alvarez-Plata and Schrooten (2004) analyzed the prognostic power of the KLR approach in the case of the Argentinean currency crisis. They have discovered that the quality of anticipation was low in this case. Budsayaplakorn et al. (2010) examined the likelihood of currency crises applying both, a multivariate probit model and a signal approach. Their findings revealed that signal approach could deliver an effective warning system and, that in the case of five Asian countries, it outperformed the probit model. They have identified that international reserves, stock market indices and gross domestic product were indicators that provide the most reliable crisis signal.

On the other hand, parametric approaches, namely discrete choice models (probit and logit models), have been proposed in numerous studies. The discrete choice models solve some of the limitations of the signal approach. The outcome of the discrete choice models provides a numerical value of the likelihood of currency crises. Furthermore, there is a possibility of testing the statistical significance of independent variables and assessment of their contribution to the crises prediction (Glick and Hutchison, 2013).

Some of the earliest studies that apply probit analysis were conducted by Frankel and Rose (1996) and Eichengreen et al. (1996). Frankel and Rose (1996) investigated a sample of annual panel data for 105 developing countries during the period from 1971 to 1992. Practical conclusions indicated that currency crises happened in the situation characterized by low GDP growth, high domestic credit growth and a high level of foreign interest rates. In addition, the high probability of a crisis was also related to low ratio of FDI to debt. According to their findings, the current account and government budget deficits were not significant predictors of currency crises. Eichengreen et al. (1996) tested whether currency crises could be transferred from one country to another in the form of "contagion" using a binary probit model. Their conclusions suggested that the likelihood of domestic currency crises increased by eight percent if there was a speculative attack elsewhere in the world. Frankel and Saravelos (2012) examined numerous indicators in order to explain the cross-country occurrence of the 2008-09 financial crisis. They have investigated the various leading indicators based on the extensive review of the previous literature and their aim was to determine whether indicators suitable for forecasting one round of crises were suitable for forecasting the next round and to discover the leading indicators that are most suitable predictors of currency crises. Consistent with the results, foreign exchange reserves and real exchange rate overvaluation were the most suitable indicators for currency crises forecasting. Moreover, good predictors of the currency crisis were also credit growth, current account balance and the level of external and short-term external debt. Comelli (2014) analyzed the effectiveness of logit and probit early warning systems forecast in emerging markets on a sample of 29 countries 
in the period from January 1995 to December 2012. In line with the results, the likelihood of currency crises increased when credit to the private sector increased, while it decreased when GDP growth rates were high and also when the level of net foreign assets was high. Nakatani (2018) examined the likelihood of a currency crisis on a sample of 34 developing countries using the probit method. Practical results demonstrated that productivity shocks and risk premium shocks were important predictors of currency crises. Also, the results indicated that the floating exchange rate regimes were more prone to currency crises.

Feridun (2008) surveyed the main determinants of the Turkish currency crisis in 1994 and 2000-2001 using three models: probit, logit and limited dependent models. The empirical results exposed that significant predictors of the Turkish currency crises were fiscal imbalances, portfolio investments, global liquidity conditions and fragilities in the banking sector. Miyakoshi (2000) examined the main determinants of the currency crisis in Asia using the probit model. The results showed that main causes of the Asian currency crisis were fragilities in the financial sector, reflected in the low ratio of foreign reserves to total debt and swift and irregular financial liberalization. Ari (2012) investigated the main determinants of the Turkish currency crises on a sample of the data covering the period from January 1990 to December 2008 using a multivariate logit model. His findings discovered that essential predictors of the currency crisis in Turkey were disproportionate fiscal deficits, great growth of money supply, high growth of short-term external debt, fragility of the banking system and external damaging shocks. Candelon et al. (2014) estimated the dynamic logit model and their findings exposed that regarding in-sample prediction, dynamic logit models outperformed the static one. Additionally, the predicting power of a dynamic model usually increased with the extension of the prediction horizon.

Regarding the latest approach, there are several empirical studies that apply stated innovative techniques. Ghosh and Ghosh (2003) investigated the role of macroeconomic variables and structural factors in currency crises by applying the binary recursive trees technique. Their results indicated that structural weakness was an important factor of currency crises and that there was a complex relation among macroeconomic discrepancies and structural weaknesses. Nag and Mitra (1999) assessed the performance of two approaches, the signals approach and the artificial neural network (ANN) approach, to identify leading economic indicators of the emerging currency crisis. The empirical results specified that the artificial neural network model outperformed the signals approach model. Sevim et al. (2014) analyzed the currency crises in Turkey based on the data set for the period from January 1992 to December 2011, using artificial neural network, decision trees, and logistic regression models. Developed early warning systems could precisely forecast the occurrence of the currency crisis within the subsequent 12-month period. 
Markov-switching approach is also useful for investigation the currency crisis. Ari and Cergibozan (2018) compared the predictive power of logit and Markov's regime switching method using six endogenous crisis indicators spanning the period from 1990 to 2014 on the sample of the financial crises in Turkey. The conclusions of their analysis discovered that Markov-switching model slightly outperformed the logit model. Furthermore, they showed that the main determinants of the currency crisis in Turkey were portfolio investments, the inflation rate and the ratio of bank foreign deposits to total deposits. Çeşmeci and Önder (2008) analyzed the currency crises in Turkey using three estimation techniques (OLS model, signal approach and Markov model). Their findings revealed that the main predictors of Turkish currency crises were the real-sector confidence index, the banking-sector fragility index, public debt and the ratio of budget balance to GDP. Alvarez-Plata and Schrooten (2006) examined the role of macroeconomic factors and self-fulfilling speculation in the currency crisis in Argentina using a univariate Markov-switching model. The results showed that an alteration in expectations had a significant impact on the incidence of the currency crisis in Argentina. Brunetti et al. (2008) investigated changes in the exchange rate using the Markov switching GARCH model. The empirical results showed that stock index yields, real effective exchange rates, the ratio of money supply and reserves and the yields of banks' stock indices are important factors of the currency crisis.

The research of the currency crisis in the Republic of Serbia is mostly limited and predominantly related to the theoretical basis and the causes of the emergence of currency crises. Marković (2015) investigated the usual internal and external factors of currency crises, in order to clarify the essence and fundamental causes of currency crises from the end of the twentieth century. The results of the survey showed that the inadequacy of economic policy and speculative attacks were the most important factors of currency instability. As the main determinants of currency crises the author emphasizes: long retention of appreciated exchange rate, bad monetary policy conduct, primarily in the fixed exchange rate regime and the negative impact of short-term, speculative capital. The outcome of all these factors is the spending of foreign currency reserves by the central bank and speculative currency attacks. Marinković (2009) examined the mechanism and causes of the combined banking and currency crisis in Serbia and discovered that the banking crisis was caused by the legal insolvency declaration by a group of banks. Mladenović and Petrović (2014) wanted to clarify two entirely contrary effects that large currency depreciation had on inflation by investigating two currency crises in Serbia, one in the 1980s and the second in 2008-2009. Their findings disclose that, after 2000, macroeconomic stabilization, price liberalization, labor market reforms and banking sector restructuring have resulted in the failure to spiral wages and prices and monetization of the budget deficit as it was with the first currency crisis. In the second crisis period, adjustment was made by the rise in unemployment and the increase in the reference interest rate. 


\section{Methodology}

Based on the previously discussed literature, it can be observed that there is a far greater number of multi-country studies than single country studies. One of the reasons for the low number of empirical research from the standpoints of individual countries stems from insufficient data because of which early warning systems are not statistically reliable. However, panel analysis on a sample of several countries has certain shortcomings:

i) the structural characteristics of different countries differ and, therefore, the foundation of the crisis may vary among different groups of countries. In addition, even if in some group of countries, the same variables have influence on the likelihood of crises, the extent of the influence may vary from one country to the other, as shown in Edison (2003);

ii) the predictive power of forecasts, reflected in in-sample, and out-of-sample prediction in multi-country studies, is lower than in the single country studies (Berg et al., 2005);

iii) different studies provide different determinants of currency crises and there is not enough concurrence on the basis of which the common causes of all currency crises could be determined. The main reasons for this are the different sample countries and/or sample periods used in various studies (Ari, 2012);

iv) it is more likely that currency crisis determinants will remain stable over time in a particular country than in several countries, which is also one of the main criticisms of the multi-country approach (Krznar, 2004).

Therefore, in order to determine the likelihood and causes of the currency crisis, as well as to provide adequate guidelines for prevention or mitigation of currency crises in a specific country, it is desirable to perform country-level analysis.

In this paper, we analyzed the problem of research for a period of nearly twelve years. The crisis occurrence is represented by a binary variable, whereby the binary variable takes the value one if the crisis outbreaks in the observed period and zero if there is no crisis in the observed period. Due to the dichotomous nature of the dependent variable, it is necessary to apply one of the discrete choice models. For this reason, the probit estimation technique will be applied to obtain the crisis likelihood and test the significance of the leading indicators of currency crises. The binary crisis indicator is considered as the dependent variable and is treated as an endogenous variable, which is explained by a set of macroeconomic variables (Candelon et al., 2014).

Before model specification, it is necessary to identify the crisis episodes. Hence, the first step in building an early warning system consists in identification of crisis occurrences. Nevertheless, there is no agreement in the literature regarding definition of a currency crisis. Balaga and Padhi (2017: 98) give a broad description 
of the currency crisis on the basis of a comprehensive literature review: "currency crisis is a situation where there is a rapid depreciation of country's currency or a sudden depletion of foreign reserves or combination of both and/or a sharp increase in domestic interest rates as a result of speculative attack on the currency or exodus of investments in fear of depreciation". Comelli (2013: 3) defines the currency crisis as "large depreciations of the nominal exchange rate and/or extensive losses of foreign exchange reserves over a 24-month forecast horizon".

We have decided to use the definition of a currency crisis based on the idea of exchange market pressure by Girton and Roper (1977). One of the advantages of the exchange market pressure definition of crises is that it allows the analysis of speculative attacks under both fixed and flexible exchange rate regimes (Peltonen, 2006). Most of the authors agree that the currency crisis occurs in a situation when the EMP index exceeds a certain threshold value. The EMP index is calculated as follows:

$$
E M P_{t}=\Delta E_{t}-w \Delta R_{t}
$$

where:

$E M P_{t}$ - exchange market pressure index,

$\Delta E_{t}$ - relative change in the nominal exchange rate (on a monthly basis),

$w$ - the ratio of the standard deviation of the rate of change in the nominal exchange rate of the Serbian dinar against the euro and the standard deviation of the rate of change in foreign currency reserves at the monthly level,

$\Delta R_{t}$ - relative change in the level of foreign exchange reserves (on a monthly basis).

The value of the weight is determined as the ratio of the standard deviation of the rate of change in the nominal exchange rate of the Serbian dinar against the euro and the standard deviation of the rate of change in foreign currency reserves at the monthly level. The EMP index indicates the occurrence of a currency crisis when its value is 1.5 or 2 standard deviations beyond its mean, signifying 'episodes of lower size' and 'major episodes' (Anastasatos and Davidson, 2004). In our study, we have chosen a lower limit, i.e., stricter criteria (1.5 standard deviations). The obtained EMP index represents a binary crisis with the value one in the occurrence of crisis, and zero otherwise.

$$
\begin{aligned}
& \text { Crisis }_{t}=1, \text { if } E M P_{t}>\mu_{E M P}+1.5 \sigma_{E M P} \\
& \text { Crisis }_{t}=0, \text { otherwise }
\end{aligned}
$$

When the crisis variable is defined, it is possible to continue with the model development. In this study, probit estimation technique will be applied. Contrary to the simple linear probability model, the probit model is characterized by a nonlinear 
relationship between independent variables and dependent variable. Dependent variable has a dichotomous nature, therefore it has two possible outcomes zero and one. Let $P\left(Y_{i}=1\right)$ be the probability of a currency crisis occurrence at the time $t$. The probability that $Y_{i}=1$ is equivalent to the probability that the disturbance term will take a value higher than the negative value of the deterministic part of the linear probability model (Krznar, 2004):

$$
P\left(Y_{i}=1\right)=P\left(\alpha_{0}+\sum_{(j=1)}^{k} \alpha_{j} x_{i j}+\varepsilon_{i} \geq 0\right)=F\left(\alpha_{0}+\sum_{(j=1)}^{k} \alpha_{j} x_{i j}\right)
$$

where $\mathrm{F}$ is the cumulative distribution function of the standard normal distribution. Thus, the final form of the probit model is obtained (Krznar, 2004):

$$
P\left(Y_{i}=1\right)=\frac{1}{\sqrt{2 \pi}} \int_{-\infty}^{\alpha_{0}+\sum_{j=1}^{k} a_{j} x_{i j}} e^{-\frac{t^{2}}{2}} d_{t}=\int_{-\infty}^{\alpha_{0}+\sum_{j=1}^{k} a_{j} x_{i j}} \varphi(t) d t=\Phi\left(\alpha_{0}+\sum_{j=1}^{k} a_{j} x_{i j}\right)
$$

where $t$ is random variable which follows standardized normal distribution and denotes disturbance term, $\Phi($.$) represents standardized normal distribution and \varphi($. denotes corresponding density function.

The estimation of probit regression parameters is done using the Maximum Likelihood method which evaluates the parameters by maximizing the probability function. Probit method has several advantages (Ari, 2012): it evaluates all early warning indicators at the same time and detects the marginal contribution of each indicator, which then allows the elimination of the irrelevant ones from the analysis, and also provides standard statistical tests that evaluate robustness of the results. Nevertheless, bearing in mind the non-linear nature of the model, the challenge is to interpret the estimated coefficients of the predictors.

The next step in the model development is the selection of data. In this study, we have used monthly data over the period from January 2007 to May 2018, covering 137 months. The main reason for starting the analysis in 2007 is the fact that Serbia became an independent country in mid-2006, because the State Union of Serbia and Montenegro ceased to exist.

Following the recent trend in the early warning indicators literature regarding the selection of the data, the monthly data instead of quarterly or annual data are used in the analysis, in order to provide better detection of the unexpected crises and deviations of crisis determinants (Candelon et al., 2014). Also, monthly data provide better model's robustness. The data sources used in the analysis are the International Financial Statistics of the IMF (2018), National Bank of Serbia (2018), Statistical Office of the Republic of Serbia (2018) and the Belgrade Stock Exchange (2018). Since monthly data were not available for the gross domestic product (GDP) variable, they are obtained by interpolation using the cubic spline method. The interpolation of the data was conducted based on the available quarterly data. 
The empirical model should identify the key determinants of currency crises in the Republic of Serbia. A set of economic indicators is selected based on the previous literature. The model is specified as follows:

$$
\begin{aligned}
Y_{t}= & \beta_{0}+\beta_{1} \text { M2FER }_{t}+\beta_{2} \text { BELEX }_{t}+\beta_{3} \text { CAGDP }_{t}+\beta_{4} E X P_{t}+\beta_{5} I M P_{t}+ \\
& +\beta_{6} \text { RERM }_{t}+\beta_{7} \text { PORTINV }_{t}+\beta_{8} I N D_{t}
\end{aligned}
$$

where $Y_{t}$ represents dichotomous dependent variable (crisis variable), $\beta_{0}$ denotes intercept term and $\beta_{1}, \beta_{2}, \beta_{3}, \beta_{4}, \beta_{5}, \beta_{6}, \beta_{7}, \beta_{8}$ represent estimated effects.

The specified model employs eight explanatory variables. Following the approach presented by Ari and Cergibozan (2018), the selected explanatory variables can be classified into three categories: macroeconomic variables (M2FER, BELEX and IND), variables that represent external vulnerability (CAGDP, EXP, IMP and RERM) and variables that represent financial liberalization and banking-sector vulnerability (PORTINV). In this way, the mayor causes of all three generations of currency crises are covered.

M2FER represents the broad money M2-to-foreign exchange reserves ratio. M2FER assess the capability of the central bank's reserves to meet the liabilities of the banking sector. The increase in this ratio is considered as a signal of increased likelihood of the crisis. The main reason for this is that just before the crisis, there is a possibility that the central bank is going to sell a considerable quantity of official reserves. Also, instantaneously after the crisis, the investors will start to convert their savings into a foreign currency. In other words, the increase in this ratio caused by a loss of foreign exchange reserves of the central bank or by excessive monetary expansion is probable to amplify the likelihood of crises since the central bank is not able to cover the demand of depositors who want to convert their domestic currency into a foreign currency in the aftermath of the crisis (Ari and Cergibozan, 2018). This variable is frequently considered as one of the possible determinants of currency crises. Positive influence of this measure on the crisis likelihood is shown in Berg and Pattillo (1999), Tamgac (2011), Glick and Hutchison (2000) and Ari and Cergibozan (2018). Therefore, the positive impact of this variable on the probability of the crisis is expected.

BELEX signifies the stock market index and it shows the performance of entities whose shares are quoted on the Serbian stock market. In addition to showing the state of the financial market, it indicates the degree of development of the entire economy. The reduction in the value of this index may signify current or probable economic slowdown. On the other hand, the downfall of the stock market indicates an upcoming crisis. Hence, there is a negative relation between the value of the stock exchange index and the probability of crisis, as shown in Budsayaplakorn et al. (2010). Consequently, we expect evidence of a negative correlation between BELEX and the crisis likelihood. 
IND stand for industrial production index and it indicates the strength of the real sector. The growth of the industrial production points to the strengthening of the economy, which positively influences on investment decisions, leads to an increase in capital inflows and reduces the pressure on domestic currency. It is therefore expected that the growth of industrial production reduces the probability of a crisis (Ari and Cergibozan, 2018; Ari, 2012).

CAGDP represents the current account balance as a percentage of GDP and shows country's level of international competitiveness. The existence of outsized negative current account balance (current account deficits) indicates elevated degree of vulnerability. When the deficit exceeds a certain level, market participants may estimate that the deficit is unsustainable and assume currency depreciation (Licchetta, 2011). Therefore, the negative influence of this indicator is expected since the higher value of the surplus indicates the lower probability of the crisis, which is demonstrated in Bucevska (2011), Licchetta (2011) and Cuaresma and Slacik (2009).

EXP denotes export growth. The decline in export growth may signify a decrease in competitiveness in the international goods market, which may be due to an overvalued domestic currency (Al-Assaf et al., 2013). In addition, the decline in exports compromises a country's capability to earn foreign exchange to finance an existing current account deficit (Bucevska, 2011). Also, currency crises are closely associated with overvalued real exchange rates, and therefore exports are expected to decline before the crisis (Brüggemann and Linne, 1999). Accordingly, the decline in export growth increases the crisis potential, which is proven by Budsayaplakorn et al. (2010), Zhao et al. (2014), Glick and Hutchison (2000) and Al-Assaf et al. (2013). Consequently, we expect to find the evidence of a negative relation between the increase in exports and the likelihood of a crisis.

IMP signifies import growth. The augmentation of import growth could suggest that the exchange rate is overvalued. As a consequence, a decline in competitiveness and a worsening in the current account position is expected (Al-Assaf et al., 2013). It creates an opportunity for speculative attacks on the currency, too. Therefore, the increase in imports indicates a higher probability of a currency crisis, as demonstrated in Jacobs and Kuper (2005). So, a positive relation is expected.

RERM represents real exchange rate misalignment. This indicator has been determined as the real exchange rate deviation from its simple linear trend. RER is determined using the equation

$$
R E R=N E R * \frac{P_{E U}}{P_{S E R}}
$$

where NER represents nominal exchange rate, $P_{E U}$ and $P_{S E R}$ represent consumer price indexes in the EU and Serbia, respectively. The linear trend represents the type of a simple regression model where the independent variable denotes a series of equally 
spaced numbers. An overvaluation of domestic currency has several directions of action. Although short-term capital should be attracted, there may also be a reduction in the country's international competitiveness, which may create unsustainable external deficits (Ari and Cergibozan, 2018). Therefore, a positive relation is expected since an overvalued domestic currency would indicate an increase in the crisis probability, as shown in Berg and Pattillo (1999) and Ari and Cergibozan (2018).

PORTINV denotes portfolio investments and this indicator is used as a proxy for financial liberalization, which is considered as one of the key determinants of the crises according to the second, and especially, third generation models (Radelet and Sachs, 1998). Financial liberalization causes the vulnerability of the domestic economy. It is especially dangerous too rapid liberalization of economies with underdeveloped financial markets. However, since there is evidence of a positive correlation between portfolio investments and crises probability (Ari and Cergibozan, 2018), and also evidence of a negative relation (Feridun, 2008), the expected influence cannot be anticipated.

\section{Empirical data and analysis}

The values of the dependent variable described in the methodological part will first be displayed. Values above 0.0490 indicate periods with a currency crisis. Since the end of 2013, a very stable period has been noticed, without any episodes of currency crises. After that follows a graphical presentation of the variables which were included in the EMP index.

Graph 1: Evolution of the EMP index in the Republic of Serbia for the period from October 2006 to May 2018

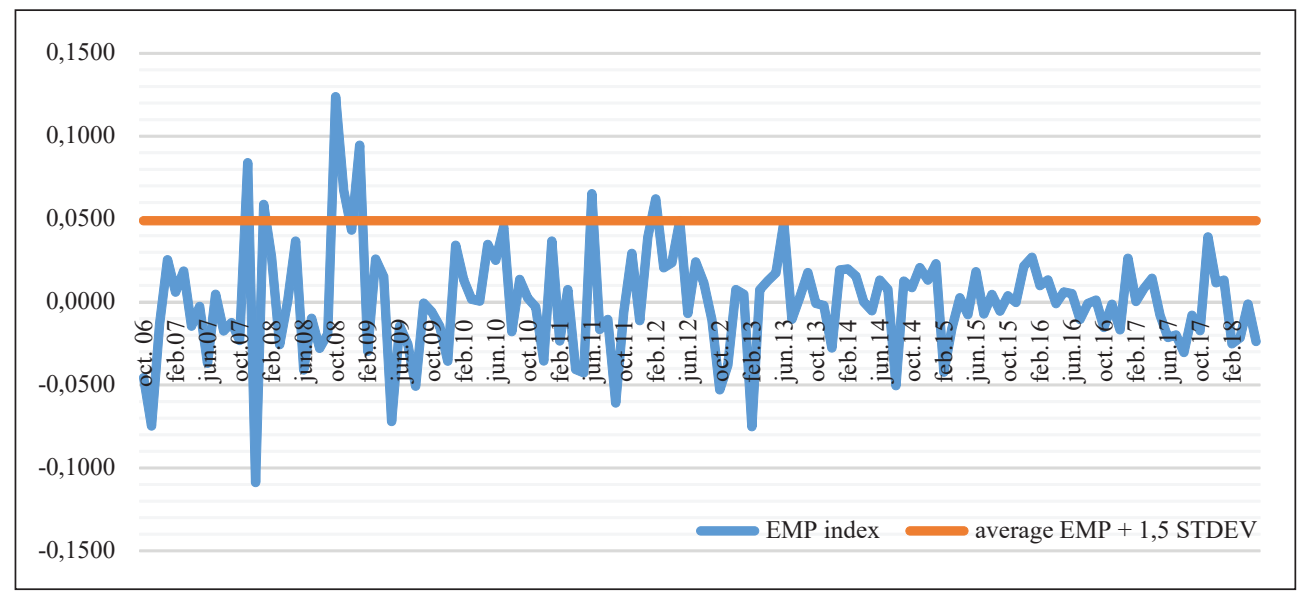

Source: Authors' calculation 
Graph 2: Evolution of the nominal exchange rate of the Serbian dinar against the euro in the Republic of Serbia for the period from October 2006 to May 2018

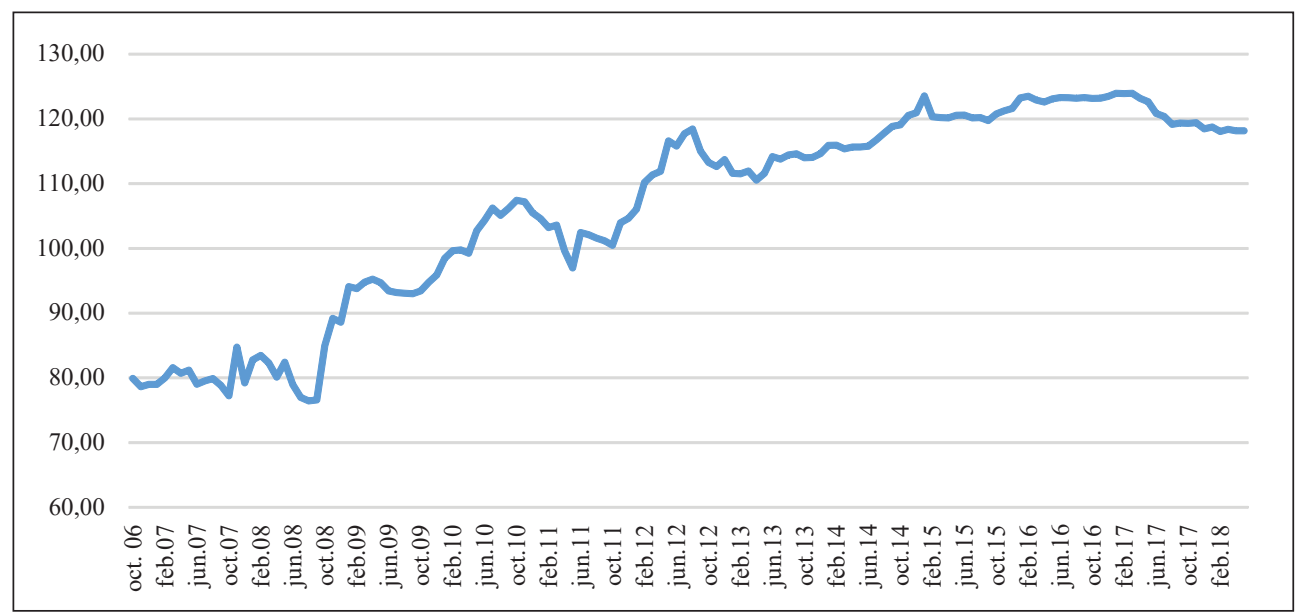

Source: Authors' presentation on the basis of the data downloaded from https://www.nbs.rs/ internet/cirilica/80/index.html

Graph 3: Evolution of the exchange rate reserves in the Republic of Serbia for the period from October 2006 to May 2018 (In million EUR)

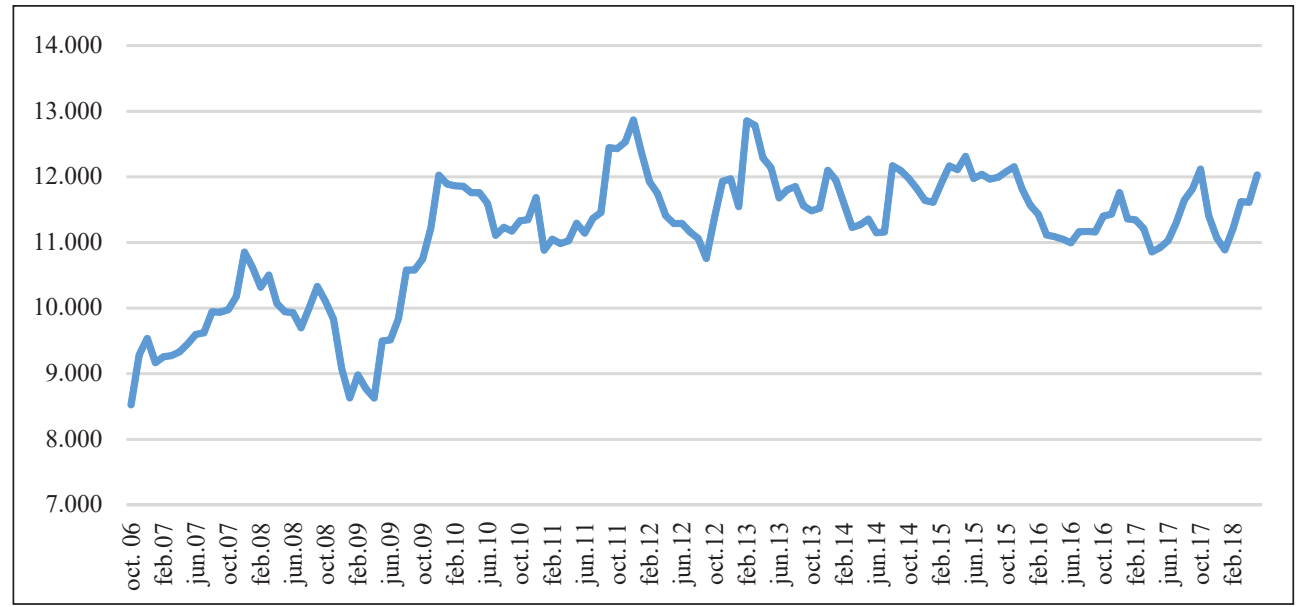

Source: Authors' presentation on the basis of the data downloaded from https://www.nbs.rs/ internet/cirilica/80/index.html 
Another significant issue that should be consider is related to time series properties of the variables, since the discrete choice models require stationary variables (Peltonen, 2006). For this reason, the standard univariate augmented Dickey-Fuller test and the Phillips-Perron unit-root test were conducted. The test results indicate that for all variables, except BELEX and M2FER ratio, the null hypothesis of a unit root was rejected at a minimum of $10 \%$ significance level. BELEX and M2FER represents $I$ (1) series and their first differences are stationary. Consequently, after differentiation the assumption of the stationarity of all variables in the analysis is fulfilled. Results of the estimated probit model are shown in the Table 1.

Table 1: Probit estimation of the influence of explanatory variables on the currency crises likelihood in the Republic of Serbia

\begin{tabular}{|l|c|}
\hline \multicolumn{1}{|c|}{ Variable } & Coefficient \\
\hline \multirow{2}{*}{ M2FER } & 0.153 \\
& $(0.147)$ \\
\hline \multirow{2}{*}{ BELEX } & -0.004 \\
& $(0.002)^{*}$ \\
\hline \multirow{2}{*}{ CAGDP } & -18.145 \\
\multirow{2}{*}{ EXP } & $(10.351)^{*}$ \\
\hline \multirow{2}{*}{ IMP } & 0.063 \\
& $(0.036)$ \\
\hline \multirow{2}{*}{ RERM } & -0.073 \\
& $(0.034)^{* *}$ \\
\hline \multirow{2}{*}{ PORTINV } & 0.108 \\
\multirow{2}{*}{ IND } & $(0.056)^{*}$ \\
\hline \multirow{2}{*}{ cons } & 0.001 \\
& $(0.002)$ \\
\hline
\end{tabular}

Note: ${ }^{*} \mathrm{p}<0.1 ; * * \mathrm{p}<0.05 ; * * * \mathrm{p}<0.01$; Standard errors in parentheses; M2FER - M2 to foreign exchange reserves ratio; BELEX - stock market index; CAGDP - current account balance as a percentage of GDP; EXP - export growth; IMP - import growth; RERM - real exchange rate misalignment; PORTINV - portfolio investments; IND - industrial production index

Source: Authors' calculation

LR statistics used to test the joint null hypothesis that all the slope coefficients except the constant are zero is rejected at significance level of $1 \%$ (LR chi2 (7) $=$ 21.77 , Prob $>$ chi $2=0.0028$ ). The value of McFadden $\mathrm{R}^{2}$ shows reasonably good goodness-of-fit of the model (0.3571). 


\section{Results and discussion}

According to the EMP index, for the observed period there were 8 crisis periods (November 2007, January, October and November 2008, January 2009, June 2011, February and May 2012). The results in Table 1 mainly provide support to previous findings in empirical literature on currency crises. Consistent with the estimated model, there are several leading indicators of currency crises. The overvaluation of the exchange rate has been one of the causes of the currency crises in the Republic of Serbia. This finding is in accordance with our expectations. The current account balance also has an important role in the currency crises occurrence. The higher value of surplus indicates the lower probability of the crisis. The main indicator of the crisis is precisely tied to this indicator. This is in line with our anticipations. The stock market index has a negative influence on the likelihood of a currency crisis, meaning that the increase in the stock market index value indicates the lower probability of the currency crisis. This is also in accordance with the results from the previous literature. However, our finding shows that the increase in imports reduces the probability of the currency crisis, which is contrary to the results from the previous literature where the growth of imports (due to greater competitiveness of foreign goods on the domestic market caused by the weakening of their currency) influences the diversion of demand to foreign products, leading to a reduction in gross domestic product, the growth of the exchange rate and the reduction of foreign exchange reserves. In practice, another transmission channel has appeared.

Most of the crisis periods are related to the emergence and turbulence of the last major world crisis since the end of 2007. It was precisely during this period that currency crises were much stronger than the remaining three periods during 2011 and 2012, when there were certain macroeconomic problems caused by poor economic policy. Shortly thereafter, economic stabilization measures were undertaken with a view to regulating public finances, as well as certain structural reforms. Managing a moderately restrictive fiscal policy has allowed the relaxation of monetary policy measures, and there has also been a stabilization of inflation and exchange rate.

In relation to the early warning model for the crises, CAGDP, RERM, BELEX and IMP are variables that have shown a significant impact on the outbreak of the currency crisis. In order to improve the current account of the balance of payments, it is necessary to actively encourage production and exports, for example ICT and agriculture, which are not import dependent sectors. The upward conjuncture will also contribute to the BELEX index to move in the desired direction, as one of the indicators of economic activities of market entities. Another indication of external vulnerability and acting on the expectation of speculators is RERM. Overvalued currency may be a signal to short-term speculative capital that the central bank will not be able to defend the exchange rate with foreign exchange reserves and will have a strong depreciation of the national currency. However, the policy of the National Bank of Serbia in the past 6 years has shown good results in terms of reducing 
inflationary expectations and strengthening foreign reserves, by conducting a stable foreign exchange rate policy that is appropriate for importers and exporters. Also, the improved macroeconomic position and favorable expectations created will enable a more relaxed monetary and fiscal policy. Although the overvalued currency increases the possibility of a currency crisis, the depreciation of the national currency in the Republic of Serbia is rapidly transferred to inflation, which reduces the real exchange rate and competitiveness of exports. Another reason that supports the current policy of the exchange rate is the structural characteristics of the Serbian economy and the fact that depreciation of the domestic currency can significantly increase the costs in the export sector. Based on results, we think that external shocks have a dominant influence on the possibility of a currency crisis. Compared to previous research at the world level, most analyzed variables showed the expected impact, except for exports and imports. Unlike exports, the growth of imports is a statistically significant indicator and we believe that due to the high import dependence of the most important export sectors of the Serbian economy, there was a negative correlation between the growth of imports and the likelihood of the occurrence of the currency crisis. In fact, the decrease in imports will increase the likelihood of the currency crisis, as production and exports will be significantly reduced due to the lack of adequate domestic substitutes.

\section{Conclusions}

This paper aimed to present the main determinants of currency crises from the recent episodes of currency crises in the Republic of Serbia. Based on an ex post analysis, using probit technique, it has been established that in the predictions of future currency crises an important role is played by the unfavorable movement of variables indicating external vulnerability (current account deficits in relation to the GDP, imports, real exchange rate misalignment). The results of our study show that the currency crisis in the Republic of Serbia is the most favorable to the type of currency crisis according to which the events from the external environment (taking into account the explanatory, statistically significant variables) are dominant. From this it can be seen that the basic hypothesis of research, which is given in the introductory remarks, is confirmed. Economic policy measures must be aimed at stimulating exports and reducing the import dependence of the economy (primarily from energy sources and inputs in the machinery and industry of transport vehicles), which in turn will stimulate the growth of gross domestic product. Bearing in mind that the model has shown that the increase in imports reduces the likelihood of currency crises in the Republic of Serbia (which is a novelty compared to studies undertaken in the case of other countries, both developed and developing countries), for future research it is necessary to examine in more detail the connection between this and the fact that there is a high import content of exports of the Republic of Serbia. Our study faces with some limitations. Firstly, although the model contains several 
variables which are selected based on the findings in the previous studies, there is a possibility that some relevant variables are omitted. This primarily refers to data from the financial sector (for example, domestic credit data) which were available for a shorter period of time and it was not possible to make their inclusion in the analysis without reducing the number of observations and jeopardizing the prediction power of the model. Secondly, the specified probit model observes the currency crisis as an explicit episode in time, disregarding the dynamic nature of crisis. Thirdly, the variables used in the model are economic indicators which are analyzed individually. Yet, some combinations of indicators may be better predictors of the currency crisis. Despite the above mentioned limitations, we believe that the estimated probit model has good predictive power of the currency crisis occurrence in the Republic of Serbia, with reasonably good goodness-of-fit. The specified model represents the basis for creation of a more comprehensive model that will include more variables, particularly institutional and political variables.

\section{References}

Al-Assaf, G., Al-Tarawneh, A., Alawin, M. (2013) "Determinants of currency crisis in Jordan a multinomial logit model", European Scientific Journal, ESJ, Vol. 9, No. 34.

Alvarez-Plata, P., Schrooten, M. (2004) "Misleading indicators? The Argentinean currency crisis", Journal of Policy Modeling, Vol. 26, No. (5), pp. 587-603, doi: 10.1016/j.jpolmod.2004.01.008.

Alvarez-Plata, P., Schrooten, M. (2006) "The Argentinean currency crisis: A Markov-Switching model estimation", The developing economies, Vol. 44, No. 1, pp. 79-91, doi: 10.1111/j.1746-1049.2006.00004.x.

Anastasatos, T. G., Davidson, I. R. (2004) "How homogenous are currency crises? A panel study using multiple-response models", https://dspace.lboro.ac.uk/ dspace-jspui/handle/2134/329.

Ari, A. (2012) "Early warning systems for currency crises: The Turkish case", Economic Systems, Vol. 36, No. 3, 391-410, doi: 10.1016/j.ecosys.2012.07.001.

Ari, A., Cergibozan, R. (2018) "Currency crises in Turkey: An empirical assessment”, Research in International Business and Finance, Vol. 46, pp. 281293, doi: 10.1016/j.ribaf.2018.04.001.

Babić, A., Žigman, A. (2001) “Currency crises: Theoretical and empirical overview of the 1990s", No. 5. The Croatian National Bank, Croatia.

Balaga, M. R., Padhi, P. (2017) "Evaluating Indian economy's vulnerability to currency crisis", Theoretical and Applied Economics, Vol. 24, No. 3.

Belgrade Stock Exchange, (2018) https://www.belex.rs/trgovanje/izvestaj/mesecni [Accessed 13. 12. 2018] 
Berg, A., Pattillo, C. (1999) "Predicting currency crises: The indicators approach and an alternative", Journal of international Money and Finance, Vol. 18, No. 4, pp. 561-586, doi: 10.1016/S0261-5606(99)00024-8.

Berg, A., Borensztein, E., Pattillo, C. (2005) "Assessing early warning systems: how have they worked in practice?", IMF staff papers, Vol. 52, No. 3, pp. 462502, doi: 10.5089/9781451847284.001.

Brunetti, C. et al. (2008) "Markov switching GARCH models of currency turmoil in Southeast Asia", Emerging Markets Review, Vol. 9, No. 2, pp. 104-128, doi: 10.1016/j.ememar.2008.02.005.

Brüggemann, A., Linne, T. (1999) "How good are leading indicators for currency and banking crises in Central and Eastern Europe? An empirical test", No. 95. IWH Discussion Papers.

Bucevska, V. (2011) "An analysis of financial crisis by an early warning system model: The case of the EU candidate countries", Business and Economic Horizons, Vol. 4, No. 1, doi: 10.15208/beh.2011.2.

Budsayaplakorn, S., Dibooglu, S., Mathur, I. (2010) "Can macroeconomic indicators predict a currency crisis? Evidence from selected Southeast Asian countries”, Emerging Markets Finance and Trade, Vol. 46, No. 6, pp. 5-21, doi: 10.2753/ree1540-496x460601.

Burnside, C., Eichenbaum, M., Rebelo, S. (2008) "Currency Crises Models", In Durlauf S.N., Blume L.E. (eds) The New Palgrave Dictionary of Economics. Palgrave Macmillan, London, Vol. 1-8, pp. 1243-1246, doi: 10.1007/978-1349-58802-2_350.

Candelon, B., Dumitrescu, E. I., Hurlin, C. (2014) "Currency crisis early warning systems: Why they should be dynamic", International Journal of Forecasting, Vol. 30, No. 4, pp. 1016-1029, doi: 10.1016/j.ijforecast.2014.03.015.

Çeşmeci, Ö., Önder, A. Ö. (2008) "Determinants of Currency Crises in Emerging Markets: The Case of Turkey", Emerging Markets Finance and Trade, Vol. 44, No. 5, pp. 54-67.

Comelli, M. F. (2013) "Comparing parametric and non-parametric early warning systems for currency crises in emerging market economies", No. 13-134, International Monetary Fund.

Comelli, M. F. (2014) "Comparing the performance of logit and probit Early Warning Systems for currency crises in emerging market economies", No. 1465, International Monetary Fund.

Cuaresma, J. C., Slacik, T. (2009) "On the determinants of currency crises: The role of model uncertainty", Journal of Macroeconomics, Vol. 31, No. 4, pp. 621632, doi: 10.1016/j.jmacro.2009.01.004.

Eichengreen B., Rose, A. K., Wyplosz, C. (1996) "Contagious currency crises: first tests", Scandinavian Journal of Economics, Vol. 98, No. 4, pp. 463-84, doi: 10.1016/S0261-5606(99)00023-6. 
Edison, H. J. (2003) "Do indicators of financial crises work? An evaluation of an early warning system", International Journal of Finance and Economics, Vol. 8, No. 1, pp. 11-53, doi: 10.2139/ssrn.238249.

Feridun, M. (2008) "Currency crises in emerging markets: the case of postliberalization Turkey", The Developing Economies, Vol. 46, No. 4, pp. 386-427, doi: 10.1111/j.1746-1049.2008.00071.x.

Frankel, J. A., Rose, A. K. (1996) "Currency crashes in emerging markets: An empirical treatment", Journal of international Economics, Vol. 41, No. 3-4, pp. 351-366, doi: 10.1016/S0022-1996(96)01441-9.

Frankel, J., Saravelos, G. (2012) "Can leading indicators assess country vulnerability? Evidence from the 2008-09 global financial crisis", Journal of International Economics, Vol. 87, No. 2, pp. 216-231, doi: 10.1016/j.jinteco.2011.12.009.

Girton, L., Roper, D. (1977) "A monetary model of exchange market pressure applied to the postwar Canadian experience", The American Economic Review, Vol. 67, No. 4, pp. 537-548.

Ghosh, S. R., Ghosh, A. R. (2003) "Structural vulnerabilities and currency crises", IMF Staff Papers, Vol. 50, No. 3, pp. 481-506, doi: 10.2307/4149942.

Glick, R., Hutchison, M. (2000) "Banking and currency crises: How common are the twins?" Financial Crises in Emerging Markets, pp. 35-69. doi: 10.1017/ cbo9780511572159.003.

Glick, R., Hutchison, M. M. (2013) "Models of currency crises", In The Evidence and Impact of Financial Globalization, pp. 485-497, doi: 10.1016/B978-0-12397874-5.00004-X.

International Financial Statistics of the IMF, (2018) https://www.imf.org/en/Data [Accessed 12. 12. 2018]

Jacobs, J. P., Kuper, G. H. (2005) "Currency crises in Asia: a multivariate logit approach", No. 200506. University of Groningen, CCSO Centre for Economic Research.

Kaminsky, G., Lizondo, S., Reinhart, C. M. (1998) "Leading indicators of currency crises", Staff Papers, Vol. 45, No. 1, pp. 1-48. doi: 10.2307/3867328.

Kaminsky, G. L., Reinhart, C. M. (1999) "The twin crises: the causes of banking and balance-of-payments problems", American economic review, Vol. 89, No. 3, pp. 473-500, doi: 10.1257/aer.89.3.473.

Krugman, P. (1979) "A model of balance-of-payments crises", Journal of money, credit and banking, Vol. 11, No. 3, pp. 311-325, doi: 10.2307/1991793.

Krznar, I. (2004) "Valutna kriza: teorija i praksa s primjenom na Hrvatsku", Hrvatska narodna banka, pp. 1-39.

Licchetta, M. (2011) "Common determinants of currency crises: The role of external balance sheet variables", International Journal of Finance and Economics, Vol. 16, No. 3, pp. 237-255, doi: 10.1002/ijfe.425. 
Marinković, S. (2009) "Mechanics and causes of twin crises: the case of recent currency - banking disturbances in Serbia". $8^{\text {th }}$ International Conference Challenges of Europe: Financial crisis and climate change, Faculty of Economics Split, Bol-Split, pp. 183-200.

Marković, M. (2015) "Domestic and external factors of currency crises", Facta Universitatis, Series: Economics and Organization, Vol. 12, No. 2, pp. 121-128.

Miyakoshi, T. (2000) "The causes of the Asian currency crisis: empirical observations", Japan and the World Economy, Vol. 12, No. 3, pp. 243-253, doi: 10.1016/S0922-1425(00)00038-4.

Mladenović, Z., Petrović, P. (2014) "Currency Crash and Exchange Rate PassThrough: A Tale of Two Crises in Serbia", Eastern European Economics, Vol. 52, No. 2, pp. 65-84, doi: 10.2753/EEE0012-8775520204.

Nakatani, R. (2017) "The Effects of Productivity Shocks, Financial Shocks, and Monetary Policy on Exchange Rates: An Application of the Currency Crisis Model and Implications for Emerging Market Crises", Emerging Markets Finance and Trade, Vol. 53, No. 11, pp. 2545-2561, doi: 10.1080/ 1540496X.2016.1216836.

Nakatani, R. (2018) "Real and financial shocks, exchange rate regimes and the probability of a currency crisis", Journal of Policy Modeling, Vol. 40, No. 1, pp. 60-73, doi: 10.1016/j.jpolmod.2017.10.004.

Nag, A., Mitra, A. (1999) "Neural networks and early warning indicators of currency crisis", Reserve Bank of India Occasional Papers, Vol. 20, No. 2, pp. $183-222$.

National bank of Serbia. Statistics. (2018) https://www.nbs.rs/internet/cirilica/80/ index.html [Accessed 23. 11. 2018]

Obstfeld, M. (1986) "Rational and Self-fulfilling Balance-of-Payments Crises", American Economic Review, Vol. 76, No. 1, pp. 72-81, doi: 10.3386/w1486.

Peltonen, T. A. (2006) "Are Emerging Market Currency Crises Predictable? - a Test”, ECB Working Paper No. 571, Available at SSRN: https://ssrn.com/ abstract $=872529$.

Radelet, S., Sachs, J. (1998) "The onset of the East Asian financial crisis", No. w6680, National bureau of economic research, doi: 10.3386/w6680.

Sevim, C. et al. (2014) "Developing an early warning system to predict currency crises", European Journal of Operational Research, Vol. 237, No. 3, pp. 10951104, doi: 10.1016/j.ejor.2014.02.047.

Statistical Office of the Republic of Serbia, (2018) http://data.stat.gov.rs/?caller $=$ SDDB, [Accessed 23/11/2018]

Tamgac, U. (2011) "Crisis and self-fulfilling expectations: The Turkish experience in 1994 and 2000-2001", International Review of Economics and Finance, Vol. 20, No. 1, pp. 44-58, doi: 10.1016/j.iref.2010.07.005. 
Zhao, Y. et al. (2014) "Leading Indicators of Currency Crises: Are They the Same in Different Exchange Rate Regimes?", Open Economies Review, Vol. 25, No. 5, pp. 937-957, doi: 10.1007/s11079-014-9315-y.

\title{
Odrednice valutnih kriza u Republici Srbiji ${ }^{1}$
}

\author{
Ivana Marjanović ${ }^{2}$, Milan Marković ${ }^{3}$
}

\begin{abstract}
Sažetak
Cilj ove studije je prevladati nedostatak empirijskih istraživanja koja se bave glavnim čimbenicima valutnih kriza u Republici Srbiji, analizirajući razdoblja valutne krize $i$ kreirajući sustav ranog upozoravanja kako bi se predvidjele nadolazeće valutne krize. Ovaj rad istražuje odrednice epizoda valutne krize u razdoblju od siječnja 2007. do svibnja 2018.godine koristeći ekonometrijsku analizu i na temelju toga daje prijedloge kreatorima ekonomske politike. Pokazalo se da su dominantni čimbenici oni koji su uglavnom povezani s utjecajem čimbenika iz vanjskog okruženja, što je važno u procjeni i predviđanju potencijalnih kriza u Republici Srbiji. Konkretnije, dobiveni rezultati ukazuju na to da su precijenjenost nacionalne valute, saldo tekućeg računa kao postotak BDP-a, uvoz i burzovni indeks statistički značajne varijable.
\end{abstract}

Ključne riječi: valutna kriza, sustav ranog upozoravanja, EMP indeks, probit model

JEL klasifikacija: C25, F30, F31, F47

1 Rad je urađen u okviru projekta Ministarstva prosvjete, znanosti i tehnološkog razvoja Republike Srbije, broj 179066, pod nazivom "Poboljšanje konkurentnosti javnog i privatnog sektora umrežavanjem kompetencija u procesu europskih integracija Srbije".

${ }^{2}$ Istraživač pripravnik, Sveučilište u Nišu, Inovacijski centar, Univerzitetski trg 2, 18000 Niš, Srbija. Znanstveni interes: operacijska istraživanja. Tel.: +381 18528 655. E-mail: ivana. veselinovic@eknfak.ni.ac.rs. Osobna web stranica: http://www.icun.ni.ac.rs/index.php/sr/ ivana-marjanovic (osoba za kontakt).

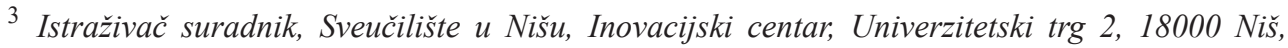
Srbija. Znanstveni interes: ekonomska politika. Tel.: +381 6428851 34. E-mail: markovicmilan89@gmail.com. Osobnaweb stranica: http://www.icun.ni.ac.rs/index.php/sr/ milan-markovic. 